\title{
Rio 2016: zika vírus e a defasagem noticiosa entre o on-line e o impresso no agendamento das olimpíadas do Brasil
}

\section{Rio 2016: zika virus and the news gap between the online and printed agenda of the Olympic Games in Brazil}

\author{
Beatriz Dornelles | Pontifícia Universidade Católica do Rio Grande do Sul \\ Professora titular da Pós-Graduação em Comunicação Social da Famecos, na PUCRS, \\ com Pós-Doutorado em Jornalismo pela Universidade Fernando Pessoa, Porto \\ E-mail: biacpd@pucrs.br \\ Marcel Neves Martins | Pontifícia Universidade Católica do Rio Grande do Sul \\ Doutorando em Comunicação Social na PUCRS \\ E-mail: neves.marcel@gmail.com
}

\begin{abstract}
Resumo
No contexto da realizaçáo de megaeventos esportivos no Brasil, este artigo tem como objetivo refletir sobre as práticas de agendamento das Olimpíadas Rio 2016 em relação à problemática do zika vírus pela Folha de S. Paulo (plataforma on-line) e pela Zero Hora (jornal impresso). O método utilizado é a análise de conteúdo, de Laurence Bardin. A amostra compreende o mês de fevereiro de 2016. Foram localizadas 19 matérias na Folha e três matérias em Zero Hora. A partir disso, trabalhamos sobre a defasagem noticiosa entre esses veículos de comunicação. Os resultados indicam que o agendamento de cada veículo está vinculado aos fluxos da informação em cada plataforma midiática. $\mathrm{Na}$ Folha, há uma cobertura intensiva e difusa, enquanto em Zero Hora o agendamento é seletivo e concentrado.
\end{abstract}

Palavras-Chave: Agendamento; olimpíadas; Rio 2016.

\begin{abstract}
In the context of mega sports events in Brazil, this article aims to reflect of the Olympic Games 2016 agenda practices regarding the issue of zika virus by Folha de S. Paulo (online media) and Zero Hora (newspaper printed). The method used is the analysis of contente of Laurence Bardin. The sample is the month offebruary 2016. It was located 19 news in Folha and three news in Zero Hora. From that, we work on the news gap between these media. The results indicate that the schedule of each vehicle is linked to information flows in each media. In Folha, there is an intensive and diffused coverage, while in Zero Hora the agenda is selective and concentrated.
\end{abstract}

Keywords: Agenda; Olympic Games; Rio 2016 


\section{Introdução}

Nos últimos anos o Brasil foi sede de megaeventos esportivos, como a Copa das Confederações Fifa, em 2013, e a Copa do Mundo Fifa, em 2014. Neste ano é a vez do país receber os Jogos Olímpicos, no Rio de Janeiro. A cobertura jornalística desses acontecimentos oportunizou e ainda possibilita a realizaçáo de reflexóes em nível acadêmico a respeito dos processos de comunicação nas mídias. Com interesse na interface "comunicação e esporte", estudamos desde 2013, no Programa de Pós-Graduação em Comunicação Social da PUCRS, a produção de conteúdos do jornal Zero Hora, de Porto Alegre (RS), sobre a Copa do Mundo. No contexto da preocupação com a midiatização desses megaeventos, procuramos refletir neste espaço sobre as práticas de agendamento das Olimpíadas Rio 2016 pelos jornais Folha de S. Paulo - na plataforma on-line - e Zero Hora - na plataforma impressa. Temos como escopo a compreensão da diferença significativa no número de notícias veiculadas por esses veículos em relação aos efeitos da proliferação de casos com o vírus da zika ${ }^{1}$ no Brasil sobre os Jogos.

Este artigo nasce a partir de visita ao site do jornal Folha de S. Paulo em que nos deparamos com notícias relativas a declaraçóes e preocupaçóes de competidores, países e organizaçóes, como a Organização Mundial de Saúde (OMS), sobre a problemática do vírus zika e sua incidência no país na época de realização das Olimpíadas, em agosto deste ano. Aí surgiu a ideia de trabalhar com esse tema, que é atual e tem relevância social. Como trabalhamos no doutorado com o jornal Zero Hora, fomos levados a investigaçáo do que estava sendo publicado nesse diário sobre a relação do zika vírus com as Olimpíadas. Para nossa surpresa, não encontramos em $\mathrm{ZH}$ todas as notícias visualizadas num primeiro momento na Folha On-line. Assim, estendemos - e delimitamos - nossa pesquisa para todo o mês de fevereiro de 2016 e confirmamos nossa hipótese inicial, a de que há uma defasagem entre o que foi noticiado pela Folha de S. Paulo em seu site na internet e o que foi noticiado pelo jornal Zero Hora em sua versão impressa - foram encontradas 19 notícias na Folha e apenas três em ZH. Isso nos levou a refletir sobre as particularidades do agendamento de cada uma das publicaçóes e meditar sobre o sentido da diferença desse fluxo noticioso.

Em âmbito metodológico, trabalhamos com a análise de conteúdo, de Laurence Bardin. Realizamos num primeiro momento a leitura flutuante, quando tivemos os contatos iniciais com as notícias publicadas na Folha e em Zero Hora. Formulamos a hipótese e o objetivo, que é o de compreender os processos de agendamento da Olimpíada a partir a problemática do vírus zika nesses jornais. Delimitamos o período de análise como o mês de fevereiro 2016 e realizamos levantamento das notícias publicadas na seção de Esporte. Para acessar o conteúdo de $\mathrm{ZH}$, pesquisamos a versão digital do jornal impresso por uma questáo de viabilidade, pois somos assinantes da mesma e não tínhamos em mãos as edições de fevereiro da versão física do jornal. Em relação à Folha, fomos no campo de busca do site e inserimos a palavra-chave Esporte. Com isso, foram relacionadas todas as notícias dessa 
editoria, de modo que pudemos localizar todo o conteúdo publicado nesse mês, podendo selecionar as matérias que tratam da relação do vírus da zika com as Olimpíadas Rio 2016. Depois, agrupamos as matérias de cada veículo e passamos ao processo de categorização dessas unidades de registro para análise temática a partir da característica mais saliente que cada conjunto de documentos tornou evidente.

Epistemologicamente, nossa reflexão se apoia na teoria do agendamento - ou hipótese da agenda-setting. Consideramos que a veiculação de notícias sobre o vírus da zika em relação a realizaçáo dos Jogos Olímpicos é fruto de operaçóes do campo jornalístico e midiático no sentido de alertar a população sobre os efeitos que a proliferação do vírus pode ter sobre os Jogos. Nesse sentido, a médio prazo pode vir a afetar o comportamento social, no sentido de promover açóes de educativas e de precaução da população para evitar que a doença faça mais vítimas justo na época das competiçôes. Ainda, o agendamento funciona para compreender o conjunto de assuntos que desde já são destacados como tópicos salientes para a opinião pública e tendem a pautar as conversaçóes em torno das Olimpíadas.

\section{Referencial teórico: a teoria do agendamento}

A comunicação jornalística de um megaevento esportivo como as Olimpíadas é envolvida por lógicas singulares próprias ao campo midiático. Tendo como contexto pressupostos básicos de endereçamento da notícia como a periodicidade, a publicidade, a atualidade e a universalidade, o campo jornalístico atua na sociedade de modo a agendar a opiniáo pública conforme todo um modus operandi próprio da sua engrenagem de produção de sentidos. As ideias somente se materializam no imaginário social porque há uma capacidade da mídia através do noticiário de influenciar o pensamento e o comportamento dos sujeitos frente aos assuntos que fazem parte do cotidiano. Essa afetação acontece porque alguns temas são privilegiados em detrimento de outros, porque os espaços são finitos - mesmo na internet não "cabe tudo" e se trabalha com o tamanho das notícias - e nem todos assuntos ganham destaque, porque nem tudo se fala, porque, sobretudo, há questôes de ordem editorial que influem no processo.

Para o exercício da noticiabilidade, uma série de critérios são empregados pela organização jornalística com o intuito de dar um regramento e ordenação ao processo de informação. Os critérios funcionam como guias que comandam a produção das notícias no interior da fábrica simbólica e atuam sobre a formação da opiniáo da pública, na medida em que privilegiam uns fatos em detrimento de outros. Na cobertura de megaeventos esportivos, assim como no tratamento das questôes do cotidiano, a adoção de critérios fica expressa pelo que é e pelo que não é noticiado, basicamente, pelo enfoque que o jornal dá aos fatos relativos aos acontecimentos.

$\mathrm{O}$ agendamento do megaevento esportivo possui peculiaridades em relação ao agendamento dos assuntos do cotidiano; há, evidentemente, a proeminência de uns critérios de noticiabilidade sobre outros. A cobertura é diferente 
porque o período de saliência do acontecimento é maior em relação aos fatos do dia a dia. Ainda, há o fato substancial de que grandes acontecimentos ou megaeventos são produzidos, organizados e gestados na atualidade não somente para as massas, senão têm como foco prioritário as próprias mídias.

As dimensōes amplas de megaeventos esportivos como as Olimpíadas requerem sua inscrição em dispositivos dotados de capacidade de significância, isto é, com capacidade para sua representação, "pois o ambiente real é excessivamente grande, por demais complexo, e muito passageiro para se obter conhecimento direto. Não estamos equipados para tratar com tanta sutileza, tanta variedade, tantas modificaçóes e combinaçóes" (LIPPMANN, 2010, p. 31). Por isso, surge a necessidade de reconstrução do mundo externo; função outorgada às mídias, que cumprem o papel de endereçamento de mapas do mundo. Lippmann (2010) conclui seu raciocínio: "e embora tenhamos que agir naquele ambiente, temos que reconstruí-lo num modelo mais simples antes de poder manejá-lo. Para atravessar o mundo as pessoas precisam ter mapas do mundo" (LIPPMANN, 2010, p. 31).

Os meios de comunicação cumprem a função de guias, apresentando as notícias que indicam os assuntos mais importantes do dia, isto é, não apenas sinalizam a existência de temas e assuntos importantes como afetam e influenciam nossas percepçóes acerca do que importa conhecer. Para McCombs (2009, p. 18), "esta habilidade de influenciar a saliência dos tópicos na agenda pública veio a ser chamada da funçáo agendamento dos veículos noticiosos". Conforme o autor, os modos de enunciação midiáticos, como o tamanho de títulos, as dimensóes das matérias, as correspondências entre página de capa e página interior e os processos autorreferentes nas notícias, que se remetem umas às outras, "comunicam a saliência dos tópicos da agenda noticiosa" (McCOMBS, 2009, p. 18).

A visão de Maxwell McCombs considera que a agenda do público é fruto, em boa medida, da agenda da mídia; o jornalismo estabelece a agenda pública. Há, assim, um uso pelo público das saliências midiáticas como forma de organizar a sua agenda e decidir o que é importante no cotidiano. Mesmo dentro dessa visão, McCombs surpreende, quando considera: "os efeitos do agendamento são mais do que o resultado de quão acessível ou disponível um tópico está presente na mente do público. [...] a saliência de um tema no público não é uma questão simples de sua disponibilidade cognitiva" (McCOMBS, 2009, p. 98). Esta percepção se realiza porque percebe que, mesmo diante da cobertura ostensiva sobre determinado assunto, os sujeitos não estão vulneráveis.

Quando a cobertura jornalística e midiática trata de uma problemática como a relação das Olimpíadas no Rio, em 2016, com a proliferação de casos no Brasil com o vírus da zika e o potencial perigo para os competidores - incluída aí a possibilidade de infecção dos turistas, o que está em jogo é a importância social do tema. O estabelecimento de uma agenda de assuntos sobre a Olimpíada, pautando conversaçóes e debates em torno do acontecimento, tende a ser efetivada e ter sua saliência potencializada na opinião pública pela capacidade de envolvimento social com o fato em pauta. É uma questão de relevância do tema que 
vai determinar a sua afetação na sociedade; não é simplesmente a maior disponibilidade do assunto nas mídias que vai incidir sobre a agenda de assuntos dos indivíduos. De alguma forma, o ganho de visibilidade do tema está envolvido e determinado pelo grau de importância que adquire socialmente.

Noção cara a obra de McCombs (2009) é a de priming, que nos remete a ação de sugestionamento: "ligação entre os efeitos do agendamento, que resultam na saliência dos assuntos ou de outros elementos junto ao público, e a subsequente expressão de opiniōes sobre figuras específicas" (MCCOMBS, 2009, p. 187). Com isso, vemos que o acontecimento midiático, representativo de um acontecimento ou fato em estado bruto, nem sempre tem como propósito o relato de um evento, no entanto, como afirma Lippmann (2010), sua transfiguração. O imaginário social, portanto, se tece para além de dados do mundo, formando-se pelas articulaçóes engendradas no tecido midiático. Por vezes, para a ação do campo jornalístico não é suficiente o relato, mas o comentário e, inclusive, a provocação do acontecimento (CHARAUDEAU, 2006).

No agendamento do megaevento há uma totalidade de informação sobre o acontecimento sobre a qual a mídia vai agir estruturando uma imagem de mundo do receptor. De acordo com a hipótese da agenda-setting "[...] essa imagem - que é simplesmente uma metáfora representativa da totalidade de toda a informação sobre o mundo, que cada indivíduo tratou, organizou e acumulou pode ser pensada como um padrão em relação ao qual a informação nova é confrontada para dar-lhe o seu significado" (WOLF, 2005, p. 152-153). No processo de agendamento, novas informaçôes vêm a corroborar as informações antigas, contudo, podem entrar em conflito com as mesmas se o receptor não está esclarecido claramente sobre o tema em questão. Na cobertura do megaevento esportivo esse detalhe se faz ainda mais presente, pois como o agendamento acontece em longo prazo nem sempre o jornalismo consegue numa mesma matéria apresentar todo o conteúdo disponível sobre determinado assunto. As informaçóes vão aparecendo em cadeia, de forma contínua e complementar.

Segundo Hohlfeldt (2001), são três os pressupostos da hipótese do agendamento: o do fluxo contínuo de informação, o do tempo de influência e de afetação dos receptores pelos meios de comunicação e o relativo ao sugestionamento, em que as mídias passam a influenciar o público sobre o que pensar e falar.

Em relação ao fluxo contínuo de informação, Hohlfeldt (2001, p. 190) afirma que "verifica-se que o processo de informação e de comunicação não é, como parecem pressupor as antigas teorias, um processo fechado". O autor destaca que sofremos ao longo do dia com uma carga tão larga de informaçóes que há a emergência de um efeito de enciclopédia, em que a mídia lança mão de recursos estratégicos como a colocação de box em anexo às matérias para complementar e atualizar as notícias.

O segundo pressuposto é relativo ao tempo de agendamento da opiniáo pública pelos meios de comunicação, que "[...] influenciam sobre o receptor não a curto prazo, como boa parte das antigas teorias pressupunham, mas sim a médio e longo prazos" (HOHLFELDT, 2001, p. 190). Nesse sentido, o tratamento de problemáticas como a da proliferação do vírus da zika no Brasil próximo a realização das Olimpíadas tende a promover um debate acerca de 
açôes que podem ser tomadas em relação às competiçôes, ensejando na sociedade um engajamento na promoção de ações preventivas à ação do mosquito transmissor da doença, o Aedes Aegypti. Assim, a mídia acaba trabalhando na formação de uma consciência social em relação ao tema.

Sobre o terceiro pressuposto cabe afirmar que a teoria do agendamento prevê que a médio e longo prazo seja salientado na opiniáo pública os temas da agenda da mídia. A agenda individual e a agenda social passam a se constituir com base nos assuntos tematizados pelas mídias. No sentido da relação do vírus da zika com as Olimpíadas, haveria uma tendência de que o conjunto da sociedade adota-se uma postura de maior educaçáo e cuidado para evitar o aumento do número de casos. A problemática seria tomada pelas pessoas como um assunto de ordem pública.

Esses pressupostos têm relação com fatores como a centralidade da informação para o público. Quanto mais este conhece e está por dentro do assunto menor é sua dependência informativa sobre o mesmo. "A experiência direta, imediata e pessoal de um problema torna-o suficientemente saliente e significativo, a ponto de atenuar, em segundo plano, a influência cognitiva da mídia” (WOLF, 2005, p. 155). Na mediação da agenda-setting, a centralidade é uma variável que deve ser considerada como um de seus fatores dominantes.

Entramos noutro aspecto da problemática do agendamento: a da necessidade de orientação. Segundo McCombs (2009, p. 108), "no âmbito dos assuntos públicos, quanto maior é a necessidade de orientação de um indivíduo, mais propenso ele estará para prestar atenção na agenda da mídia com toda sua riqueza de informação sobre política e governança”. A desinformação é componente-chave nesse processo e o indivíduo que tem uma certa necessidade de orientação em relação aos temas da agenda social pode acabar buscando informaçóes junto a outras pessoas, o que pode vir a atrapalhar o agendamento midiático. $\mathrm{O}$ processo é, de certa forma, contraditório, pois, de outra forma, a conversação pode ser eficaz, na medida em que colabora para o aumento da capacidade de entendimento do mundo pelos sujeitos. A conversação pode até mesmo pautar o indivíduo em relação à agenda da mídia e ampliar o seu raio de compreensão dos fenômenos sociais, pois o ser social dotado de determinada capacidade cognitiva pode vir a cruzar informaçóes e melhor filtrar o que a mídia diz.

Como aponta McCombs (2009), os temas vão emergir na formação da opinião pública, sendo um momento de responsabilidade ímpar para o profissional da comunicação, que vai ser exigido eticamente nesse trabalho de seleção dos temas da agenda, a tematização, que de acordo com Wolf (2005, p. 165),

[...] é um procedimento informativo que faz parte da hipótese da agenda-setting, representando uma modalidade que lhe é particular: tematizar um problema significa, na realidade, colocá-lo na ordem do dia da atenção do público, dar-lhe a importância adequada, salientar sua centralidade e sua significatividade em relação ao fluxo normal da informação não-tematizada. (WOLF, 2005, p. 165)

Hohlfeldt (2001, p. 232) define a tematização como "[...] a colocação na pauta do público receptor de um determinado tema, com todas as suas variantes e desdobramentos, dando-lhe uma aura de importância e urgência”. A questão 
da importância vai ser destacada na agenda midiática conforme decisóes editoriais tomadas no interior do veículo de comunicação. Os assuntos tendem a ganhar maior ou menor ênfase segundo protocolos próprios ao campo jornalístico. Há, no caso dos jornais, a questão do espaço, por exemplo, que define o tamanho que cada assunto vai receber. Outro fator importante em relação à tematização é a relevância, a natureza pública do tema, como aponta Wolf (2005). "Nem todo acontecimento ou problema é suscetível de tematização, apenas o que denotam alguma relevância político-social” (WOLF, 2005, p. 166). O autor argumenta que a mídia tematiza dentro de limites que ela não define e que estâo longe de seu alcance e num território que simplesmente reconhecem e cultivam.

A focalização, o framing, o vínculo e o uso de porta-vozes são identificados por Wolf (2005) como quatro fases do processo de agendamento. Num primeiro momento temos a ênfase sobre o acontecimento em si, instante em que um fato ou conjunto de fatos será destacado dos demais e selecionado para ser agendado. A focalizaçáo tende a aumentar à medida do tempo e tem como pico o momento em que o acontecimento se desenvolve. Depois é a vez do enquadramento (framing), vez em que se apresenta um quadro interpretativo a respeito do assunto coberto e se propóe formas de representaçáo do acontecimento. Com o enquadramento promove-se o acontecimento em perspectiva, de modo que são apresentados os ângulos preferenciais para abordagem do mesmo, já se mostrando visíveis as saliências da agenda midiática. Na terceira fase, "cria-se um vínculo entre o objeto ou o evento e um sistema simbólico, de modo que o objeto torna-se parte de um panorama social e político reconhecido [...]" (WOLF, 2005, p. 179). Diríamos que é nesta fase em que se dota o acontecimento de inteligibilidade, na medida em que ele é contextualizado em relação aos fatos que já se destacam na pauta social por uma continuidade em seu tratamento. A última fase está ligada a capacidade do tema em "personificar-se em indivíduos que se tornem seus 'porta-vozes”" (WOLF, 2005, p. 179).

\section{Uma cobertura intensiva: múltiplas vozes na Folha On-line}

Do dia $1^{\circ}$ ao 29 de fevereiro de 2016 localizamos 19 notícias da seção de Esportes do site da Folha de S. Paulo que tematizam a problemática do vírus da zika em relação a realização das Olimpíadas Rio-2016, no Brasil. É uma publicação média de pouco mais de uma notícia a cada dois dias. Um ritmo, de certa forma, intensivo de cobertura jornalística como esse indica a possibilidade de uma variedade de ângulos para abordagem do tema. Nesse caso, a variação se dá, basicamente, entre a preocupação de competidores com a presença do vírus na época dos Jogos, a tomada de precauçóes por países para evitar possíveis contaminaçôes nos membros de suas delegações, a desvinculação da questão zika com a Olimpíada, a confirmação de realização das competiçôes, a negativa de não-participação das naçóes no megaevento, e o posicionamento de países quanto a participação deles nos Jogos.

Em meio a diversidade de assuntos, se destaca o fato de que há uma espécie de "pessoalização" das notícias, o que fica evidente nos títulos delas, mesmo quando trata-se de enunciar que foi um país ou uma organização que 
fez determinado anúncio - caso em que fica saliente o uso da metonímia como figura de linguagem. Os títulos são, portanto, variados, mas reúnem esse aspecto em comum de indicar um sujeito na ação; como nos exemplos a seguir: "Autoridade médica do COI diz que não se cogita adiamento da Rio-2016", "Dilma recomenda roupas compridas a atletas da Rio-16 para evitar doenças", "Goleira da seleção americana teme zika e diz que não viria ao Rio hoje", "EUA vão contratar especialistas para orientar sobre zika antes da Rio-2016", "OMS diz que incidência do vírus da zika vai diminuir antes da Rio-2016”, “Zika não é um tema olímpico', diz prefeito do Rio".

A sucessão de notícias com o revezamento de "atores" envolvidos na problemática da afetação da Olimpíada pelo zika promove uma falação sobre o acontecimento esportivo; mais que isso, acaba por dar vazão a um acontecimento específico, que é a incidência do vírus no Brasil e, mais especificamente, no Rio de Janeiro, lugar de realizaçáo dos Jogos. Nesse sentido, essa cobertura intensiva da Folha, que faz emergir uma diversidade de sujeitos que dão conta de tratar do problema em questão, indica a possibilidade de compreensão do assunto pelo leitor sem que tenha um conhecimento prévio do tema. Apenas esse alerta disparado pela Folha em relação a preocupação de atletas e países com a realização dos Jogos em meio ao aumento de casos de infecçáo com o vírus da zika já é motivo de suscitar na opinião pública que se trata de assunto importante. Para Eco (1984, p. 225), "essa falação é aquela cuja função Heidegger esboçava em Sein und Zeit: 'A falação é a possibilidade de compreender tudo sem qualquer apropriação preliminar da coisa' [...]”.

A presença de múltiplas vozes na Folha sugere a tentativa de esgotamento do assunto. Cada notícia aparece como um flash que, em si, se pretende a indicar a dimensão do problema. O conjunto das informaçôes remete a uma totalidade de dizeres sobre o tema em que se estabelece, no sentido proposto por Eco (1984), uma falação sobre a falação esportiva. Há um deslocamento das questôes do esporte, relativas à prática e à disputa dos jogos, para outra esfera de debates, que é a da política. Autoridades se manifestam, países apresentam suas posiçóes e atletas se destacam como lideranças que opinam sobre o tema. "De fato a falação sobre a falação esportiva tem todas as aparências do discurso político: ali se diz o que os governantes deveriam ter feito, o que fizeram, o que queríamos que fizessem, o que aconteceu e o que acontecerá” (ECO, 1984, p. 224).

Com a exposição dessa falação em torno dos Jogos, a Folha quer dizer que está atenta e não deixa passar nada relativo à realização das Olimpíadas, principalmente, quando se trata de uma polêmica como o debate em torno da potencial desistência de atletas e países das competiçóes. A estratégia do agendamento realizado pela Folha através da promoção dessa falação sobre o acontecimento esportivo é a de alimentar um fluxo contínuo de comunicação. Para isso, se abastece em agências de notícias com o objetivo de multiplicar informaçôes. $\mathrm{O}$ veículo não fica limitado às fontes que seus profissionais têm acesso e alcance; joga com uma variedade maior de dados, de modo a noticiá-los como parte de uma cadeia informativa. A referência nas matérias às origens das 
declarações é comum, como no caso da matéria sobre a goleira da seleção de futebol dos Estados Unidos que teme o zika e disse que náo viria ao Brasil na época. No texto, a Folha faz menção à origem da declaração da atleta, dizendo que foi numa entrevista ao site da revista Sports Illustrated.

Para além de uma questão de fluxo, nos parece que um dos critérios latentes para o agendamento das Olimpíadas pela Folha em relação à problemática do zika vírus é a própria relevância do tema para a sociedade brasileira e mundial, na medida em que se trata fundamentalmente de uma questão de saúde pública; além disso há uma quantidade expressiva de envolvidos com os Jogos, sem contar nos desdobramentos políticos que a desistência de atletas e países poderia ter e nas consequências econômicas para o país com um eventual baixo índice de turistas no Brasil. Esses fatores se enquadram dentro dos critérios substantivos dos valores-notícia, segundo Wolf (2005) e Hohlfeldt (2001).

\section{Uma cobertura seletiva: potências olímpicas em destaque na Zero Hora}

Durante todo o mês de fevereiro localizamos três matérias na Editoria de Esportes do jornal Zero Hora sobre a polêmica relação do zika vírus com a realização da Olimpíada Rio 2016, no Brasil. No dia 9 de fevereiro foi publicada a matéria "Zika ameaça presença americana". No dia 10, circula a reportagem "Outra potência em alerta com o zika vírus". Já na edição do dia 26 de fevereiro Zero Hora noticia: "Aedes póe medo em goleira dos EUA".

O conteúdo da matéria do dia 9 é baseado em declaraçóes do presidente da federação americana de esgrima à Reuteurs; Donald Anthony disse à agência de notícias que o Comitê Olímpico do Estados Unidos (Usoc, na sigla em inglês) teria dito que ninguém deveria vir ao Brasil se não se sentisse confortável. Entretanto, o Usoc não teria se manifestado oficialmente sobre o caso. Os EUA são a principal potência olímpica da contemporaneidade, e a própria matéria de Zero Hora faz questão de reconhecer isso, assim como menciona a única vez em que o país ficou, por motivos políticos, de fora dos Jogos - foi na edição de 1980, realizada em Moscou, então capital da União Soviética; o contexto era a Guerra Fria instalada entre os dois países. A polêmica envolvendo a participaçáo dos americanos parece ser a razão principal pela qual Zero Hora traz essa notícia. $O$ jornal não entra nos méritos das consequências que a desistência dos EUA traria para a realização das Olimpíadas, não há o aprofundamento nesse sentido.

A reportagem do dia 10 de fevereiro, intitulada "Outra potência em alerta com o zika vírus", também segue a linha da matéria publicada no dia anterior. Noticia-se a declaração do diretor do Comitê Olímpico do Kenia, Kipchoge Keino, à imprensa do país dele, em que diz que o país não colocaria seus atletas em risco em caso de uma epidemia da doença no Brasil. Como a própria reportagem noticia, devido às declaraçóes de Keino, o Comitê queniano emitiu posição oficial dizendo que ainda não havia tomado posição sobre o caso; e o chefe da equipe olímpica do país disse que o Quênia estava se preparando para vir ao Brasil dentro do que estava planejado. Essa matéria de Zero 
Hora faz referência ao que foi noticiado no dia anterior (09/02) sobre a polêmica envolvendo a participaçáo dos americanos nos Jogos. Assim como fez na notícia do dia anterior, o veículo também se refere às garantias que o Comitê Olímpico Internacional (COI) deu no final de janeiro às delegações que virão ao Brasil sobre a diminuição do número de mosquitos Aedes Aegypti em razão das temperaturas mais baixas.

A terceira notícia encontrada nas páginas de esportes de Zero Hora é sobre as declarações da goleira da seleção de futebol feminino dos EUA, Hope Solo, de que não viria ao Brasil se o quadro da proliferação de casos de zika se mantivesse como na época do verão. Em relação às anteriores, esta é a matéria que ocupa menos espaço no jornal; diferentemente das demais não é a principal notícia da página em que se encontra. Em comum, há o fato de que Zero Hora se apropria de conteúdo que não gerou para veicular a informação. $\mathrm{O}$ jornal não escutou a atleta, mas demonstra que está atento às notícias que correm e circulam em outros veículos midiáticos.

O que fica evidente na cobertura de Zero Hora é que há uma seleção mais criteriosa do conteúdo. Note-se que duas das três notícias estão em correspondência. A publicação da matéria do dia 26 de fevereiro poderia ser interpretada como ação do jornal para "preencher espaços". Somos levados a crer nessa possibilidade, pois são apenas três matérias publicadas no período de 1 mês, e duas delas apresentam relação direta, sem contar que são destaque nas páginas em que foram publicadas, diferentemente da notícia do dia 26, que se parece mais como uma nota expandida.

Se olharmos para a cobertura de Zero Hora através dos valores-notícia de seleção de Traquina (2008), vemos que o agendamento se realiza a partir de critérios como a relevância, a novidade e o inesperado.

O inesperado é esse encadeamento dos fatos, a relação apresentada entre eles. $\mathrm{O}$ posicionamento de diversos atores sobre a problemática do zika vírus em relação às Olimpíadas não apetece. Parece que essa sucessão e alternância de vozes que tratam do assunto é algo tão comum que não chama a atenção do jornal. Mas é pelo fato curioso e de reverberaçáo de um sobre o outro e a consequente ligação entre ambos que Zero Hora apresenta a informação.

A novidade é a própria possibilidade de desistência dos Estados Unidos e do Quênia dos Jogos. Isso significa que até então não havia qualquer tipo de manifestação - oficial, oficiosa ou mesmo informal - a respeito do assunto, e que agora se instalou uma polêmica em cada país que acaba por ser objeto de atenção porque incide na realização do megaevento esportivo, afinal, trata-se de duas potências olímpicas.

E é aí que se insere a relevância do assunto. Não é apenas uma polêmica instalada sobre a participação de duas delegaçôes, mas de dois países que são representativos em termos de Olimpíada, pois se destacam como potências, seja a nível geral, como é o caso dos Estados Unidos, seja em nível específico, como é o caso do Quênia, que apresenta os melhores corredores do mundo e se destaca, portanto, no atletismo 


\section{Defasagem entre agendamentos: uma questão de fluxo}

A diferença entre o volume de conteúdo apresentado pelo site da Folha de $S$. Paulo e o jornal Zero Hora é significativa. Como pode um mesmo acontecimento receber tratamento distinto entre dois veículos de comunicaçáo de referência? O que está por trás da diferença de quantidade de notícias veiculadas em cada mídia? Há uma relação com a característica de cada plataforma midiática? Isso tem a ver com uma questão de fluxo ou é uma questão de "angulação" temática?

Os critérios da Folha e da Zero Hora para o agendamento das Olimpíadas Rio 2016 no âmbito dos valores-notícia não são muito diferentes. A relevância social do megaevento esportivo no contexto da problemática do zika vírus é fundamental para cada veículo. O interesse social no assunto, por se tratar de uma questáo de saúde pública, é um motivo para a difusão de informaçôes sobre o tema. Nesse caso a diferença de característica entre os veículos não parece pesar em relação ao fator da relevância. Para ambos o assunto é relevante; o que muda, no contexto da relevância, é a relação com a apropriação do tema. Sem dúvida, há o imperativo de alimentação de um fluxo noticioso, mas que vai se destacar de forma diversa. Aí aparece a sua imbricação com o trabalho de angulação temática. $\mathrm{O}$ assunto é relevante para cada veículo, entretanto, em razão de uma variação na importância de fluxo, o tema vai ser apropriado conforme interesses distintos. O propósito da Folha é alimentar a falaçáo sobre o megaevento na lógica da intensidade, no quanto mais, melhor. O objetivo de Zero Hora é, sobretudo, estabelecer uma narrativa mais seletiva, com base no incomum. São finalidades que estão relacionadas com outros dois valores-notícia, já citados anteriormente: a novidade e o inesperado.

Por uma questáo de fluxo, que vai incidir na angulaçáo projetada em cada agendamento midiático do assunto, a novidade e o inesperado podem ser vistos como valores-notícia que vão funcionar de forma específica em cada veículo.

$\mathrm{Na}$ Folha, o fluxo contínuo de notícias faz com que a novidade seja qualquer fato novo em relaçáo a um fato anterior sobre o tema do zika vírus nas Olimpíadas do Rio 2016. Tudo que se sucede é apropriado para a alimentação de um fluxo incessante de conteúdo. O novo vai funcionar como o inesperado, ou melhor, o inesperado é o novo, que funciona no sentido de uma atualização das informaçóes. No contexto de um assunto socialmente relevante, a novidade é, de certa forma, esperada pela Folha. Todos os ângulos relativos ao tema são explorados como parte de um mesmo enredo. A sequência de informaçóes alimenta a dinâmica dos fatos e faz emergir um acontecimento, pautado pelo que é atual (SODRÉ, 2009), por um "evento" - o debate instalado sobre a problemática do zika vírus no Brasil - que está em desdobramento e se faz notado pelas múltiplas vozes que o acionam.

O fluxo de notícias na plataforma impressa do jornal Zero Hora é diário. Há, evidentemente, uma necessidade de preenchimento de espaços todos os dias. Contudo, como indica a cobertura de Zero Hora sobre a relação do zika vírus com a realização das Olimpíadas Rio 2016, no Brasil, não há a preocupação com a alimentação de um fluxo incessante de notícias ou mesmo com a atualização de informaçôes sobre o que se sucede a respeito de um tema socialmente relevante como esse. Aqui a vinculação do inesperado com o novo é de outro nível, isto é, 
não se coloca em termos de um "simples" processo de atualização que torna os termos equivalentes pela expectativa da imprensa sobre a geraçáo de novos conteúdos a partir do que é imprevisto. O inesperado é, para além do novo, o excepcional dele. Essa é uma relação que fica clara no agendamento da temática - zika vírus e a Rio 2016 - pela Zero Hora com a vinculação entre os fatos pelo elemento extraordinário que os une. O fluxo de notícias é seletivo, mais controlado; nem tudo que é novidade na falação sobre os Jogos é matéria para Zero Hora.

O fluxo noticioso da Folha mostra que o encadeamento entre as notícias se realiza no sentido do que se fala sobre a relação do zika com a Olimpíada. Cada pronunciamento atualiza o fato novo. O que se destaca é o tom da declaração dos atores envolvidos com a realização dos Jogos. Em Zero Hora, o aspecto declarativo se faz presente, mas nele se sobressai o fato em si. Assim, na Folha a falação gerada sobre a Rio 2016 parece que se autonomiza e ganha vida própria a ponto de se tornar um acontecimento sobre o acontecimento. Já em Zero Hora a seleçáo que restringe e determina o volume de informaçóes em circulação no periódico faz com que o fato em si - da potencial desistência de EUA e Quênia de participarem das Olimpíadas - ganhe relevo e não seja superado pela falação que gera.

\section{Conclusão}

$\mathrm{O}$ agendamento das Olimpíadas em relação à problemática do zika vírus não é homogêneo na imprensa brasileira, conforme indica a amostra pesquisada. Há diferenças substanciais no tratamento dessa questão por diferentes veículos de comunicação, como é o caso da Folha de S. Paulo e da Zero Hora. Como não pesquisamos a versão impressa da Folha (mesmo a disponibilizada em formato digital para leitura através da página do jornal na internet) e não analisamos o conteúdo on-line publicado no site de Zero Hora, nossa investigação aponta para um agendamento diverso dos Jogos que pode estar relacionado às características de cada meio - o impresso e o on-line.

De qualquer modo, fica clara a defasagem noticiosa entre dois veículos sobre um mesmo assunto. A necessidade de alimentar um fluxo contínuo de informaçóes pela Folha torna todo novo dado relativo às Olimpíadas objeto para matéria jornalística. A característica da plataforma parece afetar o processo produtivo, na medida em que tudo se publica, nada é deixado fora da agenda dessa mídia. Como o fluxo de Zero Hora náo é constante, ainda que haja uma preocupação com a alimentação diária da agenda do jornal, predomina o caráter seletivo na veiculação de notícias.

Dois termos parecem dar o sentido para o agendamento realizado por esses veículos: concentrado e difuso. Se consideramos que um mesmo assunto pode apresentar vários ângulos para abordagem jornalística, devemos ter em mente que uma cobertura como a da Folha, que promove uma falação generalizada sobre essa pauta - o zika vírus na Rio 2016 -, é difusa, pois não tem como escopo uma possível singularidade dos fatos em um acontecimento. Do contrário, Zero Hora parece concentrar sua abordagem no excepcional, na medida em que se importa com comunicados feitos por duas delegaçôes - EUA e 
Quênia. Vale ressaltar que nas Olimpíadas temos a disputa por medalhas entre países; o sentido coletivo se sobressai em relação ao individual. Esse seria um fator central para o agendamento promovido pelo jornal.

Por último, cabe notar que existem interesses distintos em jogo. Cada veículo se posiciona de um modo singular diante do megaevento esportivo. Esse posicionamento leva em consideração questôes jornalísticas - sobre o que é relevante para a opinião pública - e de mercado - em relação a estratégias de ganho da atençáo dos leitores no contexto das rotinas específicas de consumo de conteúdo deles em cada mídia

\section{Referências bibliográficas}

CHARAUDEAU, Patrick. Discurso das mídias. São Paulo, SP: Contexto, 2006.

ECO, Umberto. Viagem na irrealidade cotidiana. Nova Fronteira: Rio de Janeiro, 1984.

HOHLFELDT, Antônio; MARTINO, Luiz C.; FRANÇA, Vera Veiga (orgs.). Teorias da comunicação. Petrópolis, RJ: Vozes, 2001.

LIPPMANN. Walter. Opinião pública. Petrópolis, RJ: Vozes, 2010.

MCCOMBS, Maxwell. A teoria da agenda: a mídia e a opinião pública. Petrópolis: Vozes, 2009.

SODRÉ, Muniz. A narração do fato: notas para uma teoria do acontecimento. Petrópolis, RJ: Vozes, 2009.

TRAQUINA, Nelson. Teorias do jornalismo. A tribo jornalística - uma comunidade interpretativa transnacional. Florianópolis: Insular, 2a ed., 2008.

WOLF, Mauro. Teorias das comunicações de massa. São Paulo: Martins Fontes, 2005.

\section{Notas}

1. O zika vírus, causador da doença conhecida como zika, é transmitido em humanos pelo mosquito Aedes Aegypti, o mesmo que transmite a dengue. O vírus da zika foi associado pelo Ministério da Saúde, em novembro de 2015, ao surto de microcefalia na região nordeste - a microcefalia é uma má-formação congênita em que o cérebro do feto não se desenvolve de maneira adequada durante a gestação. No Brasil, o primeiro caso da doença foi registrado em 2014. Os sintomas são: febre e dor de cabeça; vermelhidão e dor atrás dos olhos; vômitos; manchas vermelhas e outras possíveis erupçóes na pele; e dor nas articulaçôes. Fonte: http://temas.folha.uol.com. br/aedes/zika/o-virus.shtml. Acesso em fevereiro de 2016. 